\title{
Various aspects of soil and tree layer vegetation analysis in tropical dry deciduous forest of Hastinapur
}

\author{
Poonam Khurana*, R.C Arya and Poonam Rani \\ Department of Botany, Meerut College, Meerut (U.P.), INDIA \\ *Corresponding author. E-mail: punnu.k@gmail.com
}

\begin{abstract}
Different parameters of Soil and vegetation analysis were carried out in Tropical dry deciduous forest of Hastinapur region of Uttar Pradesh. Vegetation of present study sites showed effects of various anthropogenic disturbances. The highly disturbed stand I showed low tree density while less disturbed stand III showed high tree density and good regeneration pattern. D-D curve were also drawn on the basis of the IVI of different species. Population structure of different tree species was drawn to understand the regeneration pattern. The most characteristic feature of the forest is dominance of xerophytic species and open forest canopy due to disturbances. Overgrazing and other biotic factors are making the area poor both in nutrient and top soil, which will eventually result in desertification of the Hastinapur in long run.
\end{abstract}

Keywords: Diversity, D-D curves, Importance value Index, Population Structure, Regeneration, Species composition

\section{INTRODUCTION}

It is well established fact that forest are the chief source of human economy as well as play vital role in safeguarding the complex environmental values. However forest are undergoing degradation day by day, large scale destruction of forest in many areas of plains of Uttar Pradesh has resulted in several environmental problems. The rising anthropological of human and cattle in these forest has became a serious problem for their sustainability as they are the main source of timber, fuel wood and other non timber forest products.

The growing pressure of population on these forests has depleted the good forest cover. Besides this many species has became threatened and verge to extinction. Therefore the delicate relationship between man and forest has been shattered which need a sound policy for their conservation management and sustainable development through appropriate knowledge and strategies.

Hastinapur forest region are of dry thorn type. These forests are represented in dry regions of Uttar Pradesh. The species forming the scrub vegetation are Zizyphus xylopyra, Zizyphus mauritiana, Butea monosperma, Prosopis juliflora etc. as far as the structure and function of these forest are concerned this were studied by Murty and Singh (1960)

Population structure of species in a forest can convey partly its regeneration behavior in relation to the reproductive strategy; importance is given to the number of saplings under adult tree for predicting future comparison of a forest community. Saxena and Singh
(1982) have analyzed the size class distribution of major species in several forest types of Central Himalaya. However Singh and Singh (1987) recognized five patterns of population structure given The over exploitation of forest has resulted in loss of biodiversity due to loss of habitat of many species Mishra et al.(2004); and Mani and Parthasarthy (2005). The impact of human influence on natural forest is so severe which result in loss of biological pool, which not only reduces the species diversity but also leading towards the end of the birth of the forest species. In the recent years the forest of Hastinapur region witnesses the great anthropogenic as well as biotic disturbances. These disturbances do not provide time for the ecosystem recovery and arrest the regeneration of importance plant species in the forest of the region. This not only widens the gap but also changing the species composition of forest.

The major objective of the study were (i) To study certain characteristics of soil such as physical properties and soil PH of different sites (ii) To determine density, frequency, abundance, $\mathrm{A} / \mathrm{F}$ ratio and importance value Index (IVI), Plant diversity at each forest site. (iii) To determine the dominance diversity curve and population structure of some dominant tree species occurring in each stand.

\section{MATERIALS AND METHODS}

Study site: The study site was located at $36.4 \mathrm{~km}$ north east to Meerut. It lies at $29^{\circ} 1^{\prime} \mathrm{N}$ latitude and $79^{\circ} 9^{\prime} \mathrm{E}$ longitudes. The climate of the entire study area is influenced by monsoon pattern of rainfall and $85 \%$ of rainfall occurs in rainy season during July to September 
Table 1. Analysis of the seedling, sapling and pature trees of different species occurring in the Forest stand-I. Seedlings

\begin{tabular}{cllllllllll}
\hline S.N & Species & $\mathbf{D}$ & $\mathbf{F}$ & $\mathbf{A b}$ & $\mathbf{A} / \mathbf{F}$ & $\mathbf{T B A}$ & $\mathbf{R D}$ & $\mathbf{R F}$ & RD & IVI \\
\hline 1 & Acacia nilotica & 1.55 & 85 & 1.8 & 0.021 & 3.54 & 28.97 & 25.75 & 29.23 & 83.95 \\
2 & Acacia farnesiana & 1.05 & 75 & 1.4 & 0.018 & 2.58 & 19.62 & 22.72 & 21.30 & 63.64 \\
3 & Prospis juliflora & 1.15 & 70 & 1.6 & 0.022 & 1.96 & 21.49 & 21.21 & 16.18 & 58.88 \\
4 & Tectona grandis & 0.95 & 60 & 1.5 & 0.025 & 2.55 & 17.75 & 18.18 & 21.05 & 56.98 \\
5 & Zizyphus xylopyra & 0.65 & 40 & 1.4 & 0.035 & 1.48 & 12.14 & 12.12 & 12.22 & 36.48 \\
\hline Mean & & 5.35 & 330 & 7.7 & 0.121 & 12.11 & 19.99 & 19.99 & 19.99 & 299.93 \\
\hline Saplings & & & & & & & & & & \\
\hline S.N & Species & $\mathbf{D}$ & $\mathbf{F}$ & $\mathbf{A b}$ & $\mathbf{A} / \mathbf{F}$ & $\mathbf{T B A}$ & $\mathbf{R D}$ & $\mathbf{R F}$ & $\mathbf{R D}$ & IVI \\
\hline 1 & Acacia nilotica & 1.00 & 65 & 1.5 & 0.023 & 33.30 & 40.81 & 31.70 & 40.13 & 112.64 \\
2 & Acacia farnesiana & 0.50 & 55 & 1.0 & 0.018 & 17.16 & 20.40 & 26.82 & 21.19 & 68.41 \\
3 & Prosopis juliflora & 0.50 & 45 & 1.0 & 0.022 & 15.97 & 20.40 & 21.95 & 19.72 & 62.07 \\
4 & Tectona grandis & 0.40 & 40 & 1.0 & 0.025 & 14.52 & 19.51 & 19.51 & 17.93 & 56.95 \\
\hline Mean & & 2.4 & 205 & 4.5 & 0.088 & 80.95 & 25.28 & 24.99 & 24.99 & 300 \\
\hline \multirow{2}{*}{ Trees } & & & & & & & & & \\
\hline S.N & Species & $\mathbf{D}$ & $\mathbf{F}$ & $\mathbf{A b}$ & $\mathbf{A} / \mathbf{F}$ & $\mathbf{T B A}$ & $\mathbf{R D}$ & $\mathbf{R F}$ & $\mathbf{R D}$ & IVI \\
\hline 1 & Acacia nilotica & 2.2 & 100 & 2.2 & 0.022 & 1055.0 & 26.50 & 22.72 & 28.41 & 77.63 \\
2 & Acacia farnesiana & 1.6 & 90 & 1.7 & 0.018 & 718.81 & 19.27 & 20.45 & 20.35 & 60.07 \\
3 & Acacia catechu & 1.5 & 80 & 1.8 & 0.022 & 661.35 & 18.09 & 18.18 & 17.80 & 54.07 \\
4 & Prosopis juliflora & 1.9 & 80 & 1.5 & 0.018 & 633.04 & 22.89 & 18.18 & 17.04 & 58.11 \\
5 & Dalbergia sissoo & 0.5 & 50 & 1.0 & 0.020 & 387.41 & 6.02 & 11.36 & 10.43 & 27.81 \\
6 & Tectona grandis & 0.6 & 40 & 2.3 & 0.057 & 257.88 & 7.22 & 9.09 & 6.94 & 23.26 \\
\hline Mean & & 8.3 & 440 & 10.5 & 0.157 & 3713.49 & 16.66 & 16.66 & 16.66 & 300
\end{tabular}

but on the whole climate is arid. The soil of the forest contains sand, silt and clay in different proportions. The soils of the forest were alkaline in nature.

Study of soil properties: From each site the composite soil samples were collected from $0-10 \mathrm{~cm}, 10-20 \mathrm{~cm}$ and 20-30 cm depth, packed in polythene bags and brought to the laboratory for analysis of physical and chemical properties. Moisture content was determined on dry wet basis, soil texture was determined using the sieve of different sizes. Soil $\mathrm{Ph}$ was measured using 1.5 proportions of soil and water by glass electrodes (Jackson 1968).

Quantitative analysis of vegetation; The quantitative information was carried out in the study forest site mainly for density, Frequency, abundance, A/F ratio, IVI (Importance value index) of tree layer vegetation. the tree vegetation analysis was done using quadrat method of $10 \times 10 \mathrm{~m}$ size. Total 10 quadrats were placed randomly in each forest site. On the basis of field data the tree density, frequency, abundance, A/F ratio and IVI were calculated based on the formulas as given by Curtis and McIntosh (1950) and Saxena and Singh (1982).

Dominance - diversity curve and population structure: The dominance diversity curves were developed on the basis of importance value index (IVI) of seedlings, saplings and trees for different forest sites. The IVI of each species were plotted on $\mathrm{Y}$ - axis and species on $\mathrm{X}$ axis. For making the population structure each tree species were divided into different circumference classes, Viz. seedlings were considered to be individuals $0-15 \mathrm{~cm}$ (circumference at breast height), saplings $15-30 \mathrm{~cm}$ cbh and trees above $30 \mathrm{~cm} \mathrm{cbh}$. The mature tree species were further divided.

\section{RESULTS}

Soil characteristics: The nature of soil profile, soil $\mathrm{pH}$, the nutrient cycling between the soil and trees are the important dimensions in determining the site quality. The present study observed that $\mathrm{pH}$ of the soil ranged from 7.26 on horizon B of MD site to 8.52 on Horizon C of UD site, which indicated that soil was alkaline in nature The maximum (274.40 $\mathrm{kg} \mathrm{ha}^{-1}$ ) phosphorus content was observed in horizon A of HD site whereas minimum (33.60 $\mathrm{kg} \mathrm{ha}^{-1}$ ) in horizon B of UD site. Availability of potassium ranged from $155.68 \mathrm{~kg} \mathrm{ha}^{-1}$ (horizon $\mathrm{C}$ of MD site) to $544.88 \mathrm{~kg} \mathrm{ha}^{-1}$ (horizon B of HD site). Nitrogen content varied from $165.92 \mathrm{~kg} \mathrm{ha}^{-1}$ (horizon C of UD site) to 287.26 $\mathrm{kg} \mathrm{ha}^{-1}$ (Horizon A of MD site).

Quantitative analysis of trees: The various quantitative parameters as mentioned in the objective were studied for Seedlings, Saplings and Trees in each forest stand. The result for each forest stand is described as given below.

\section{Forest stand-I}

Seedlings: The Seedlings of five tree species viz.Acacia nilotica, Acacia farnesiana, Prosopis juliflora, Tectona grandis and Zizyphus xylopyra were present. Seedlings of Acacia nilotica were dominant in the site. The total density of seedlings was $5.35 \mathrm{ind} 100 \mathrm{~m}^{-2}$. However the individual density of seedlings ranged from 0.65 to 1.55 
Table 2. Analysis of the seedling, sapling, and mature trees of different species occurring in the Forest stand-II.

Seedlings

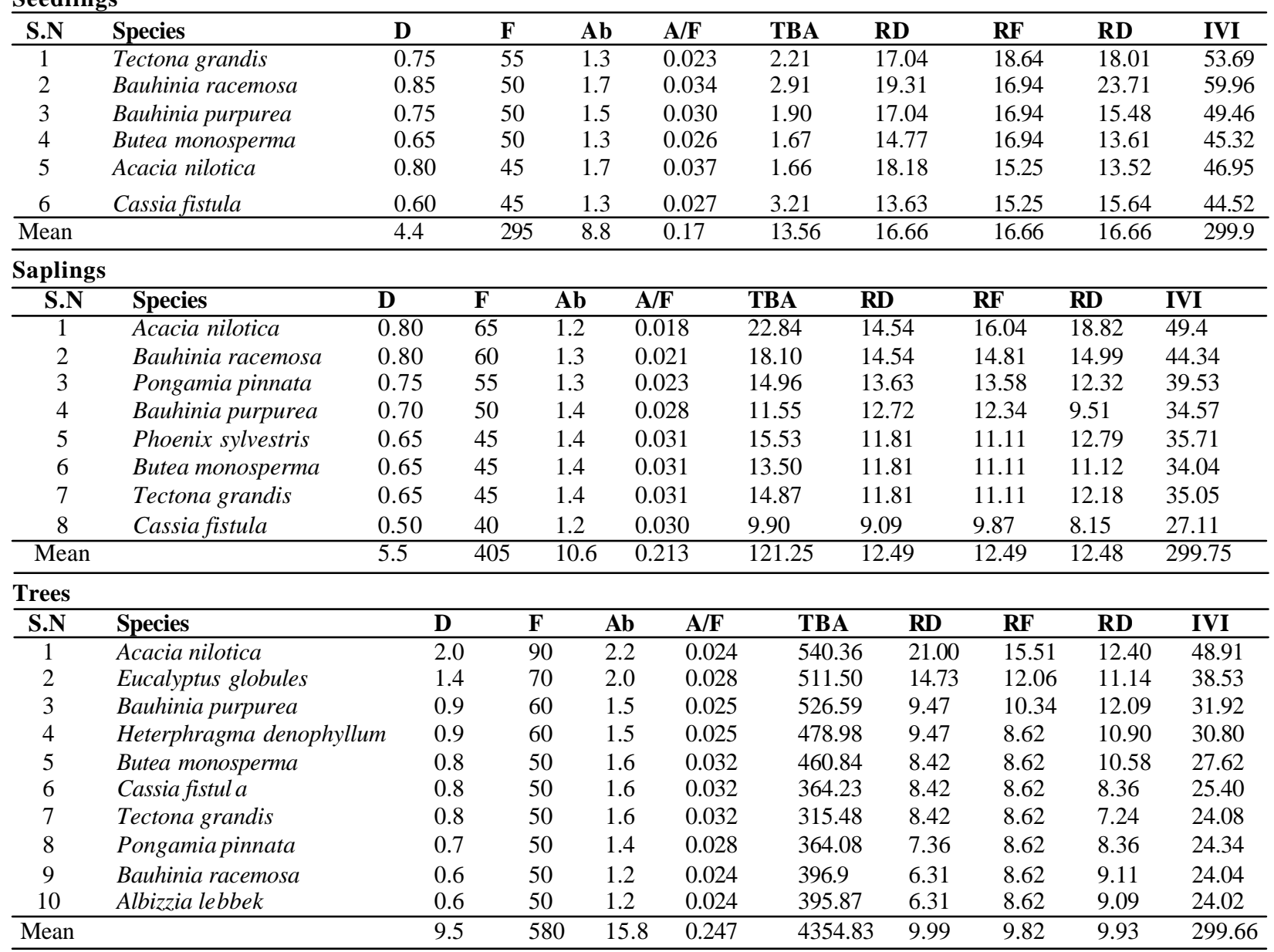

(Table-1). The frequency of individual species ranged from $40 \%$ to $85 \%$ and was maximum for Acacia nilotica. However the abundance and $\mathrm{A} / \mathrm{F}$ ratio of seedlings ranged from 1.4 ind $100 \mathrm{~m}^{-2}$ to 1.8 ind $100 \mathrm{~m}^{-2}$ and 0.018 to 0.035 (Table-1). The basal area of seedlings ranged between $1.48 \mathrm{~cm}^{2} 100 \mathrm{~m}^{-2}$ and $3.54 \mathrm{~cm}^{2} 100 \mathrm{~m}^{-2}$ and was maximum for Acacia nilotica and minimum for Zizyphus xylopyra, Acacia nilotica was the most dominant (IVI= 83.95) followed by Acacia farnesiana (IVI= 63.64).

Saplings: The Saplings of four tree species viz. Acacia nilotica, Acacia farnesiana, Prosopis juliflora and Tectona grandis were present. Total density of saplings was 2.4 ind $100 \mathrm{~m}^{-2}$. The dominant sapling was Acacia nilotica. However the individual density of saplings ranged between 0.40 and 1.00 ind $100 \mathrm{~m}^{-2}$. The frequency ranged from $40 \%$ to $65 \%$. It was maximum for Acacia nilotica and minimum for Tectona grandis, the abundance and A/F ratio varied from 1.0 to 1.5 ind $100 \mathrm{~m}^{-}$ 2 and 0.018 to 0.025 (Table-1). The basal area of saplings ranged between 14.52 and $33.30 \mathrm{~cm}^{2} 100 \mathrm{~m}^{-2}$. It was maximum for Acacia nilotica and minimum for Tectona grandis. The total basal area of forest was $80.95 \mathrm{~cm}^{2}$ 100m-2 (Table-1). The saplings of Acacia nilotica was most dominant (IVI=112.64) followed by Acacia farnesiana $(\mathrm{IVI}=68.41)$

Trees: The six tree species viz. Acacia nilotica, Acacia farnesiana, Acacia catechu, Prosopis juliflora, Dalbergia sissoo and Tectona grandis were present in the forest. Total density of trees were 8.3 ind $100 \mathrm{~m}^{-2}$. The tree density ranged from 0.5 ind $100 \mathrm{~m}^{-2}$ (Dalbergia sissoo) and 2.2 ind $100 \mathrm{~m}^{-2}$ (Acacia nilotica). The frequency ranged from $40 \%$ to $100 \%$ which was maximum for Acacia nilotica. The abundance and $\mathrm{A} / \mathrm{F}$ ratio ranged from 1.0 ind $100 \mathrm{~m}^{-2}$ to 2.3 ind $100 \mathrm{~m}^{-2}$ and 0.018 to 0.057 (Table-1). The total basal area of trees was $3713.49 \mathrm{~cm}^{2} 100 \mathrm{~m}^{-2}$. The basal area ranged from $257.88 \mathrm{~cm}^{2} 100 \mathrm{~m}^{-2}$ to $1055.0 \mathrm{~cm}^{2}$ $100 \mathrm{~m}^{-2}$. It was maximum for Acacia nilotica and minimum for Tectona grandis. The most dominant species was Acacia nilotica (IVI=77.63) in the site followed byAcacia farnesiana $(\mathrm{IVI}=60.70)$ and Prosopisjuliflora $(\mathrm{IVI}=58.11)$ (Table-1).

Acacia nilotica is most important species in this site had individuals of all size classes for telling adequate regeneration. Acacia farnesiana and Prosopis juliflora represented by more in seedlings and sapling classes than in trees indicating these are going to be most 
Table 3. Analysis of the seedling, sapling, and mature trees of different species occurring in the Forest stand-III. Seedlings

\begin{tabular}{|c|c|c|c|c|c|c|c|c|c|c|}
\hline S.N & Species & $\mathbf{D}$ & $\mathbf{F}$ & $\mathbf{A b}$ & $\mathbf{A} / \mathbf{F}$ & TBA & RD & RF & RD & IVI \\
\hline 1 & Phoenix sylvestris & 0.95 & 60 & 1.5 & 0.025 & 2.18 & 13.66 & 12.63 & 15.21 & 41.50 \\
\hline 2 & Butea monosperma & 1.00 & 60 & 1.6 & 0.026 & 2.02 & 14.48 & 12.63 & 14.09 & 41.20 \\
\hline 3 & Tectona grandis & 0.75 & 55 & 1.3 & 0.023 & 1.96 & 10.79 & 11.57 & 13.67 & 36.03 \\
\hline 4 & Cassia fistula & 0.80 & 50 & 1.6 & 0.032 & 1.64 & 11.51 & 12.52 & 11.44 & 35.47 \\
\hline 5 & Bauhinia purpurea & 0.60 & 45 & 1.3 & 0.028 & 1.83 & 8.63 & 9.47 & 12.77 & 30.87 \\
\hline 6 & Bauhinia variegate & 0.60 & 45 & 1.3 & 0.028 & 0.90 & 8.63 & 9.47 & 6.32 & 24.42 \\
\hline 7 & Acacia nilotica & 0.50 & 45 & 1.1 & 0.024 & 0.87 & 7.19 & 10.47 & 6.10 & 23.76 \\
\hline 8 & Pongamia pinnata & 0.60 & 40 & 1.5 & 0.037 & 1.03 & 8.63 & 9.42 & 7.20 & 25.24 \\
\hline 9 & Acacia catechu & 0.60 & 40 & 1.5 & 0.037 & 0.67 & 8.63 & 10.42 & 4.68 & 23.73 \\
\hline 10 & Bauhinia racemosa & 0.55 & 35 & 1.5 & 0.042 & 1.22 & 7.91 & 2.22 & 8.51 & 16.64 \\
\hline Mean & & 6.95 & 475 & 14.2 & 0.302 & 14.32 & 10.00 & 10.08 & 9.99 & 300.86 \\
\hline \multicolumn{11}{|l|}{ Saplings } \\
\hline S.N & Species & D & $\mathbf{F}$ & $\mathbf{A b}$ & $\mathbf{A} / \mathbf{F}$ & TBA & RD & $\mathbf{R F}$ & RD & IVI \\
\hline 1 & Phoenix sylvestris & 0.75 & 55 & 1.3 & 0.023 & 21.99 & 10.63 & 10.78 & 14.64 & 36.05 \\
\hline 2 & Ailanthus excels & 0.80 & 55 & 1.4 & 0.025 & 18.20 & 11.34 & 10.78 & 12.12 & 33.24 \\
\hline 3 & Tectona grandis & 0.80 & 50 & 1.6 & 0.032 & 15.34 & 11.34 & 9.80 & 10.21 & 31.35 \\
\hline 4 & Bauhinia racemosa & 0.55 & 50 & 1.1 & 0.022 & 11.51 & 7.80 & 9.80 & 7.66 & 25.26 \\
\hline 5 & Butea monosperma & 0.65 & 45 & 1.3 & 0.028 & 15.19 & 9.21 & 8.82 & 10.11 & 28.14 \\
\hline 6 & Bauhinia purpurea & 0.65 & 45 & 1.4 & 0.031 & 14.01 & 9.21 & 8.82 & 9.33 & 27.63 \\
\hline 7 & Cassia fistula & 0.70 & 45 & 1.5 & 0.033 & 11.92 & 9.22 & 8.82 & 7.93 & 25.97 \\
\hline 8 & Pongamia pinnata & 0.50 & 45 & 1.1 & 0.024 & 11.97 & 7.09 & 8.82 & 7.97 & 23.88 \\
\hline 9 & Dalbergia sissoo & 0.50 & 40 & 1.2 & 0.030 & 9.19 & 7.09 & 7.84 & 6.10 & 21.03 \\
\hline 10 & Bauhinia variegata & 0.50 & 40 & 1.3 & 0.032 & 10.78 & 7.80 & 7.84 & 7.17 & 22.81 \\
\hline 11 & Acacia nilotica & 0.60 & 40 & 1.5 & 0.037 & 10.08 & 8.51 & 7.84 & 6.71 & 23.06 \\
\hline Mean & & 7.00 & 510 & 14.7 & 0.317 & 150.18 & 9.02 & 9.08 & 9.08 & 298.42 \\
\hline \multicolumn{11}{|l|}{ Trees } \\
\hline S.N & Species & $\mathbf{D}$ & $\mathbf{F}$ & $\mathbf{A b}$ & $\mathbf{A} / \mathbf{F}$ & TBA & $\mathbf{R D}$ & RF & $\mathbf{R}$ & IVI \\
\hline 1 & Acacia catechu & 0.8 & 70 & 1.1 & 0.015 & 696.6 & 8.08 & 8.64 & 11.49 & 25.64 \\
\hline 2 & Tectona grandis & 0.7 & 70 & 1.0 & 0.014 & 431.64 & 7.07 & 8.64 & 7.11 & 22.74 \\
\hline 3 & Cassia fistula & 0.8 & 60 & 1.3 & 0.021 & 510.77 & 8.08 & 7.40 & 8.43 & 23.83 \\
\hline 4 & Ailanthus excelsa & 0.9 & 60 & 1.5 & 0.025 & 416.74 & 9.09 & 7.40 & 6.87 & 23.44 \\
\hline 5 & Butea monosperma & 0.8 & 60 & 1.3 & 0.021 & 483.38 & 8.08 & 7.40 & 7.97 & 23.39 \\
\hline 6 & Phoenix sylvestris & 0.8 & 60 & 1.3 & 0.021 & 331.6 & 8.08 & 7.40 & 5.49 & 20.89 \\
\hline 7 & Bauhinia purpurea & 0.8 & 50 & 1.6 & 0.032 & 346.19 & 8.08 & 6.17 & 6.70 & 20.14 \\
\hline 8 & Dalbergia sissoo & 0.7 & 50 & 1.4 & 0.028 & 366.09 & 8.07 & 6.17 & 7.04 & 19.26 \\
\hline 9 & Acacia nilotica & 0.5 & 50 & 1.0 & 0.020 & 418.51 & 6.05 & 6.17 & 6.89 & 18.06 \\
\hline 10 & Pongamia pinnata & 0.5 & 50 & 1.0 & 0.020 & 323.85 & 5.05 & 6.17 & 5.33 & 16.50 \\
\hline 11 & Bauhinia variegate & 0.6 & 40 & 1.5 & 0.037 & 336.06 & 6.06 & 4.93 & 5.43 & 16.36 \\
\hline 12 & Bauhinia racemosa & 0.5 & 40 & 1.2 & 0.030 & 340.06 & 5.05 & 4.93 & 5.60 & 15.53 \\
\hline 13 & Pithecolobium dulce & 0.4 & 40 & 1.0 & 0.025 & 348.70 & 4.04 & 4.93 & 5.74 & 14.40 \\
\hline 14 & Albizia lebebk & 0.4 & 40 & 1.0 & 0.025 & 270.60 & 4.04 & 4.93 & 4.45 & 13.38 \\
\hline 15 & Eucalyptus globules & 0.4 & 40 & 1.2 & 0.030 & 236.25 & 4.04 & 4.93 & 3.89 & 12.82 \\
\hline 16 & Diospyros cordifolia & 0.3 & 30 & 1.0 & 0.033 & 202.31 & 3.03 & 3.03 & 3.33 & 10.03 \\
\hline Mean & & 9.9 & 770 & 19.4 & 0.397 & 6059.35 & 6.58 & 6.24 & 6.23 & 297.21 \\
\hline
\end{tabular}

Abbreviations $\mathrm{D}=$ density, $\mathrm{F}=$ frequency, $\mathrm{Ab}=$ Abundence, $\mathrm{TBA}=$ Total Basal area, $\mathrm{RD}=$ relative density, $\mathrm{RF}=$ relative frequency, $\mathrm{RD}=$ relative Dominance, $\mathrm{IVI}=$ Importance value Index

important species in near future in near future, but the narrow middle girth classes suggested that their regeneration has been disturbed in past few years.

\section{Forest stand - II}

Seedlings: The seedlings of six tree species viz. Tectona grandis, Bauhinia racemosa, Bauhinaia purpurea, Butea monosperma, Acacia nilotica and Cassia fistula were recorded in the forest stand. Total density of seedlings was 4.4 ind $100 \mathrm{~m}^{-2}$. The density ranged from 0.60 ind $100 \mathrm{~m}^{-2}$ (Cassia fistula) to 0.85 ind $100 \mathrm{~m}^{-2}$
(Bauhinia racemosa). The frequency ranged from $45 \%$ to $55 \%$ and was maximum for Tectona grandis. Abundance of seedlings ranged from 1.3 to 1.7 ind $100 \mathrm{~m}^{-2}$ and was maximum for Bauhinia racemosa and Acacia nilotica (Table-2). However the $\mathrm{A} / \mathrm{F}$ ratio ranged from 0.020 (Cassia fistula) to 0.037 (Acacia nilotica). The basal area of individual species ranged from $1.66 \mathrm{~cm}^{2}$ $100 \mathrm{~m}^{-2}$ to $3.21 \mathrm{~cm}^{2} 100 \mathrm{~m}^{-2}$. The total basal area was 13.56 $\mathrm{cm}^{2} 100 \mathrm{~m}^{-2}$. The site was dominated by Bauhinia racemosa $(\mathrm{IVI}=59.96)$ followed byTectona grandis $(\mathrm{IVI}=$ 
Table 4. Physico-chemical properties of the soil in Forest of Hastinapur.

\begin{tabular}{|c|c|c|c|c|c|c|c|}
\hline \multirow{2}{*}{$\begin{array}{l}\text { Site/Horizon } \\
\text { Hillock }\end{array}$} & \multicolumn{3}{|c|}{ Texture } & \multirow[t]{2}{*}{ Moisture (\%) } & \multirow[t]{2}{*}{ Bulk density } & \multirow{2}{*}{$\begin{array}{l}\text { Organic carbon } \\
(\text { mean } \pm \text { S.D })\end{array}$} & \multirow[t]{2}{*}{ pH } \\
\hline & Sand & Silt & Clay & & & & \\
\hline Horizon A & 84 & 8 & 8 & 91.51 & 1.47 & $0.50 \pm 0.014$ & 7.65 \\
\hline B & 82 & 8 & 10 & 91.58 & 1.44 & $0.47 \pm 0.014$ & 8.08 \\
\hline $\mathrm{C}$ & 78 & 8 & 16 & 88.89 & 1.47 & $0.47 \pm 0.014$ & 8.23 \\
\hline \multicolumn{8}{|l|}{ Block-1 } \\
\hline Horizon A & 88 & 2 & 10 & 78.82 & 1.69 & $1.18 \pm 0.84$ & 7.45 \\
\hline B & 88 & 2 & 10 & 77.28 & 1.52 & $0.62 \pm 0.58$ & 7.26 \\
\hline $\mathrm{C}$ & 88 & 3 & 9 & 72.93 & 1.66 & $0.94 \pm 0.077$ & 7.69 \\
\hline \multicolumn{8}{|l|}{ Block-2 } \\
\hline Horizon A & 84 & 8 & 8 & 72.39 & 1.70 & $0.40 \pm 0.021$ & 8.24 \\
\hline $\mathrm{B}$ & 90 & 0 & 10 & 76.68 & 1.66 & $0.45 \pm 0.027$ & 8.38 \\
\hline $\mathrm{C}$ & 90 & 2 & 8 & 74.28 & 1.61 & $0.37 \pm 0.027$ & 8.52 \\
\hline
\end{tabular}

53.69) and Bauhinia purpurea (49.46).

Saplings: The saplings of eight tree species viz. Acacia nilotica, Bauhinai racemosa, Pongamia pinnata, Bauhinia purpurea, Phoenix sylvestris, Butea monosperma, Tectona grandis and Cassia fistula were reported in forest stand. Total density of saplings was 5.5 ind $100 \mathrm{~m}-2$. The sapling density ranged from 0.50 and 0.80 ind $100 \mathrm{~m}^{-2}$. the frequency and abundance ranged from $40 \%$ to $65 \%$ and 1.2 to 1.4 ind $100 \mathrm{~m}^{-2}$. However the $\mathrm{A} / \mathrm{F}$ ratio ranged from 0.018 to 0.031 . The basal area ranged from $9.90 \mathrm{~cm}^{2} 100 \mathrm{~m}^{-2}$ to $22.84 \mathrm{~cm}^{2} 100 \mathrm{~m}^{-2}$. it was maximum for Acacia nilotica and minimum for Cassia fistula. The total basal area of saplings was $121.25 \mathrm{~cm}^{2}$ $100 \mathrm{~m}^{-2}$. The saplings of Acacia nilotica were the most dominant species in the site $(I V I=49.40)$ followed by Bauhinia racemosa (44.34).

Trees: The total ten tree species viz. Acacia nilotica, Eucalyptus globules, Bauhinai purpurea, Haplophragma adenophyllum, Butea monosperma, Cassia fistula, Tectona grandis, Pongamia pinnata, Bauhinia racemosa and Albizzia lebebk were present in the forest stand. Total density of trees was 9.5 ind $100 \mathrm{~m}^{-}$ 2 . The frequency values were ranged from $50 \%$ to $90 \%$. The abundance and $\mathrm{A} / \mathrm{F}$ ratio were ranged from 1.2 to 2.2 ind $100 \mathrm{~m}^{-2}$ and from 0.024 to 0.032 . The basal area ranged from 395.87 to $540.36 \mathrm{~cm}^{2} 100 \mathrm{~m}^{-2}$ and was maximum for Acacia nilotica and minimum for Albizzia lebbek (Table2 ). The site was dominated by Acacia nilotica (IVI= 48.91) followed by Eucalyptus globules (IVI= 38.53). Bauhinia racemosa showed expanding population structure due to higher percentage of seedlings and saplings however lower percentage of middle size classes of Bauhinia racemosa indicated that regeneration has not been a steady process in the post Acacia nilotica showed decline in number, because not all the seedlings attain sapling stage due to mortality. In general $60 \%$ of trees of this site exhibited expanding population structure with broad base, they have sufficient number of individuals of lower size classes to replace individuals of higher size classes.

\section{Forest stand- III}

Seedlings: The seedlings of ten tree species viz. Phoenix sylvestris, Butea monosperma, Tectona grandis, Cassia

Tree
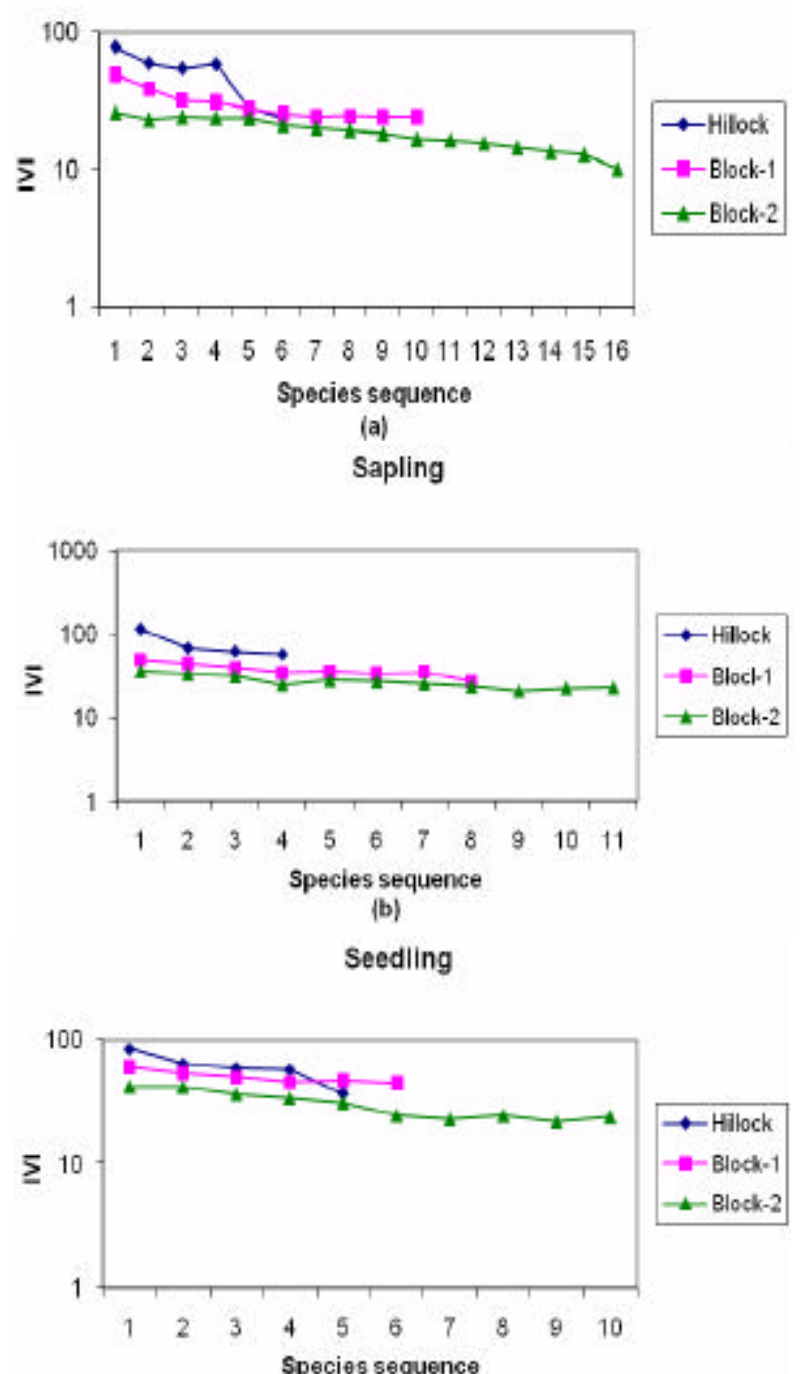

(c)

Fig. 1 . Comparision between D-D curves of trees, sapling and seedling in different study sites. 
fistula, Bauhinia purpurea, Bauhinia variegate, Acacia nilotica, pongamia pinnata, Acacia catechu and Bauhinia racemosa were present in the forest stand. The total density of seedlings was 6.95 ind $100 \mathrm{~m}^{-2}$ and 35 to $60 \%$ respectively which was found maximum for Phoenix sylvestris. The abundance of seedlings ranged from 1.1 to 1.6 ind $100 \mathrm{~m}^{-2}$ and was highest for Butea monosperma and Cassia fistula. However the A/F ratio ranged between 0.023 to 0.042 (Table-3). The basal area ranged between 0.67 and $2.18 \mathrm{~cm}^{2} 100 \mathrm{~m}^{2}$. However the total basal area of seedlings was $14.32 \mathrm{~cm}^{2} 100 \mathrm{~m}^{-2}$. The seedlings of Phoenix sylvestris $(\mathrm{IVI}=41.50)$ was dominated followed by Butea monosperma (IVI= 41.20).

Saplings:Total eleven tree species Viz.Phoenix sylvestris, Ailanthus excelsa, Tectona grandis, Bauhinia racemosa, Butea monosperma, Bauhinia purpurea, cassia fistula, Pongamia pinnata, Dalbergia sissoo, Bauhinia variegate and Acacia nilotica were present in the forest stand. Total density was 7.00 ind $100 \mathrm{~m}^{-2}$. Value of density ranged between 0.50 to 0.80 ind $100 \mathrm{~m}^{-2}$ and it was maximum for Ailanthus excelsa and Tectona grandis (Table-3). Frequency ranged between $40 \%$ and $55 \%$. Abundance ranged from 1.1 ind $100 \mathrm{~m}^{-2}$ to 1.6 ind $100 \mathrm{~m}^{-2}$ and was maximum for Tectona grandis. however the A/F ratio ranged from 0.022 to 0.037 and was maximum for Acacia nilotica (Table-3). The maximum basal area was reported for $\left(21.99 \mathrm{~cm}^{2} 100 \mathrm{~m}^{2}\right)$ for Phoenix sylvestris and minimum $9.19 \mathrm{~cm}^{2} 100 \mathrm{~m}^{-2}$ for Dalbergia sissoo. The total basal area was $150.18 \mathrm{~cm}^{2} 100 \mathrm{~m}^{-2}$. The saplings of Phoenix sylvestris (IVI= 36.05) were dominated in the site followed by Ailanthus excelsa $(\mathrm{IVI}=33.24)$ andTectona grandis $(\mathrm{IVI}=$ 31.35)

Trees: Total sixteen tree species viz. Acacia catechu, Tectona grandis, Cassia fistula, Ailanthus excels, Butea monosperma, Phoenix sylvestris, Bauhinia purpurea, Dalbergia sissoo, Acacia nilotica, Pongamia pinnata, Bauhinia variegate, Bauhinia racemosa, Pithecolobium dulce, albizzia lebebk, Eucalyptus globules and Diospyros cordifolia were present in the forest stand. The total density of trees was 9.9 ind $100 \mathrm{~m}^{-2}$ and individual tree density ranged from 0.3 to 0.8 ind $100 \mathrm{~m}^{-2}$. The frequency was reported to be ranged from $30 \%$ to $70 \%$ (Table-3). Abundance of trees ranged from 1.0 to 1.6 ind $100 \mathrm{~m}^{-2}$ and was maximum for Bauhinia purpurea. The A/ $F$ ratio ranged from 0.014 to 0.037 . Total basal area ranged between 202.31 and $696.6 \mathrm{~cm}^{2} 100 \mathrm{~m}^{2}$. It was maximum for Acacia catechu and minimum for Diospyros cordifolia. Acacia catechu was the most dominated species (IVI=25.64) followed by Tectona grandis (IVI=22.74) Cassia fistula $(\mathrm{IVI}=23.83)$ and Ailanthus excelsa $(\mathrm{IVI}=$ 23.44) (Table-3).

Acacia catechu are represented by broad seedling base indicating expanding population structure. Tectona grandis has highest percentage of individuals in seedling and sapling classes than in trees indicating that it is going to be more important species in near future, this trend is followed by Cassia fistula, Pongamia pinnata, Acacia nilotica, Bauhinia purpurea, Butea monosperma and Phoenix sylvestris.

Dominance diversity curve:The dominance diversity curve was developed on the basis of IVI for each category i.e Seedlings, Saplings and Trees. Seedlings, saplings and trees at forest stand I showed log normal distribution, while the curve for forest stand II and III represents intermediate position between log normal and geometric. (Fig-1).

\section{DISCUSSION}

The forests of northern plain area of west Uttar Pradesh are facing various biotic and anthropogenic pressures Keeping in mind all the associated problems, it was found necessary to study the forest resources of Hastinapur, which not only protect the environment but also provide the basic needs of community residing in nearby areas, but the recent growing demand of growing population and tourism activities in this area has created various disturbances in the existing forest resulting in loss of phytodiversity. The present study was based on the quantitative information of tree layer of forest with special reference to density, frequency, abundance, distribution pattern, basal area, Important value index (IVI) and certain soil characteristics. The forest area was divided in to three forest stands according to the composition of forest species, degree of disturbances and soil variation.

Total 19 tree species were reported in the studied forest stands, of which the dominant and subdominant species were Acacia nilotica, Tectona grandis, Bauhinia racemosa, Phoenix sylvestris, Bauhinia purpurea present in each forest stand. The most important dominant species was Acacia nilotica. The findings were discussed and compared on the basis of following points: Results of soil moisture distribution pattern in the soil profile of different study site showed that forest stand I has higher moisture percentage than forest stand II and III, as forest stand I has the Acacia nilotica and Dalbergia sissoo as the dominant species which holds more moisture than other species, as well as the rainfall at stand I is absorbed by surface layer by self mulching while at stand II and III portion of rain fall may be intercepted by the vegetation interception loss as reported by, George (1978) and Dabral and Rao (1968). Soil PH was highest for forest stand III and lowest for stand III (Table-4). There were lowest number of trees at forest stand I as compared to stand II and III, as stand I is frequently subjected to biotic interference which has wiped out a number of plant species, also biotic interference in forest causes remarkable change in vegetation diversity and species composition (Verma et 
al.,1997). Upadhaya et al.(2004) studied diversity and population characters of woody species in subtropical humid forest ecosystem exposed to disturbance in Meghalaya and their studies revealed that disturbance of mild intensity enhanced species richness with altering the tree population structure of the community. Pande (2006) studied regeneration behavior of important tree species in relation to disturbance in Satpura plateau M.P and concluded that present and past disturbance adversely affect the regeneration and composition of different tree species

There was great variation in the range of basal cover in studied stands. Trees of stand I showed higher girth classes which indicates that this site is dominated by trees of mature age and values of basal cover fall in range reported by Singh et al. (1981) for silent valley. The trees with high basal area indicate the best performance of species, and low basal area either demarcated the chance occurrence of the species or biotic disturbance of the past.

Comparatively less number of saplings was recorded for stand I while stand II and III showed highest number of saplings. Density of sapling layer decreased from low (Stand III) to high disturbed site. Across the study forest sites maximum seedling individuals were recorded at stand III while lowest number were recorded from stand II. Across the studied forest sites maximum seedling individuals were recorded at forest stand III, while lowest number were recorded from forest stand II. At stand I there was dominance of seedlings of Acacia nilotica which is reflected in its high IVI value (83.95), at stand II highest IVI value (59.96) was recorded for Bauhinia racemosa and at stand III seedlings of Phoenix sylvestris showed highest IVI (41.50).

The occurrence of diverse type of seedling at forest stand III indicated the more favorable conditions for growth as compared to forest stand II and I. As observed during study stand III has closed canopy and lowest disturbances, thus ensuring shady and moist environment for regeneration of seedling while at stand II and I tree canopy is getting open, also grazing and trampling by cattle also affect the soil structure by making it compact thus altering the habitat which is less suitable for the establishment of seedling, besides this grazing, insects, pest and pathogenic agents, influence the IVI by removing the terminal reproductive parts by trampling and otherwise damaging the vegetation prop gules. All these are most effective biotic factors for influencing the growth and development of vegetation.
The forest of Hastinapur is under threat due to proximation of anthropogenic pressure giving rise to rampant looping, overgrazing and clear falling for cultivation. Documenting the fast depleting i.e. (density, frequency, abundance) etc. approach is of utmost priority to develop an effective monitoring system in order to conserve and manage the relict forest bioresearches and to decide where to invent scarce conservation resources.

\section{REFERENCES}

Curtis, J.T. and Mac Intosh, R.P. (1950). The interaction of certain analytic and synthetic phytosociological characters. Ecology. 31: 434-455.

Dabral, B.G. and Subba, Rao (1968). Interception studies in Chir and Teak plantations.

George, M. (1978). Interception, steamflow and through fall in Eucalyptus hybrid plantation. Indian Forester, 104 (11): 719-726.

Jackson, M.L. (1968). Soil chemical analysis .Prentice Hall. New Delhi 498 pp.

Mani, S. and Parthasarthy, N. (2005) Biodiversity assessment of trees in five inland tropical evergreen forest of peninsular India. Systematics and Biodiversity, 3(1): 1-12.

Mishra, B.P, Tripathi, O.P, Tripathi, R.S. and Pandey, H.N. (2004). Effect of anthropogenic disturbance on plant diversity and community structure of sacred groove in Meghalaya northeast India. Biodiversity and Conservation, 13:2 421-436.

Murty, Y.S. and Singh, V.(1960) New plant records for the upper Gangetic Plain from Meerut and its Neighbourhood. Research contribution No.30 from the School of plant Morphology,Meerut college Meerut, Vol 27 B ,1-5 pp.

Pande, P.K. (2006). Regeneration behavior of important tree species in relation to disturbance in joint forest management adopted village. Forest in Satpura plateau. M.P India. Indian forestar (Jan): 91-104.

Saxena, A.K. and Singh, J.S. (1982). A phytosociological analysis of forest communities of a part of Kumaun Himalaya. Vegetation, 50: 3-22.

Singh, J.S. and Singh, S.P. (1987). Forest vegetation of Himalaya. Botanical Review 52(1): 82-192.

Singh, J.S., Singh,S.P.,Saxena, A.K. and Rawat, Y.S. (1981). the silent valley forest ecosystem and possible impact of proposed hydroelectric project. Report on the silent valley study. Ecology research circle. Kumaun University, Nainital $70 \mathrm{p}$.

Upadhaya, K., Pandey, H.N., Lawp, S. and Tripathi, R.S. (2004). Diversity and population characters of woody species in subtropical humid forest exposed to disturbance in Meghalaya north East India. Tropical Ecology, 45(2): 303-314.

Verma, R.K., Totey, N.G. and Gupta, B.N. (1997). Analysis of forest vegetation in the permanat preservation plot of Tamna in Orissa. Indian Forester, 123 (11): 1007-1016. 